\title{
THE ROLE OF CIVIL SOCIETY IN ELECTIONS The KwaZulu-Natal Democracy and Elections Forum - reducing conflict dynamics and promoting peace ${ }^{1}$
}

\section{Shauna Mottiar}

Dr Shauna Mottiar is Senior Research Fellow at the Centre for Civil Society,

University of KwaZulu-Natal

e-mail mottiar@ukzn.ac.za

\begin{abstract}
The role of civil society in elections often takes the form of support for the institutional processes of a democratic election as well as the more substantive development of a democratic electorate. Civil society does, however, have a role to play in reducing election-related conflict dynamics and promoting a peaceful electoral environment. This paper examines the role of the KwaZulu-Natal Democracy and Elections Forum (KZNDEF) in elections in KwaZulu-Natal. The paper examines the role played by the KZNDEF's five subcommittees in and their impact on the deepening of democracy, the reduction of conflict dynamics and the promotion of peace in KwaZulu-Natal, a province plagued with election-related violence.
\end{abstract}

\section{INTRODUCTION}

The role of civil society in elections often takes the form of support for the institutional processes of a democratic election as well as the more substantive development of a democratic electorate. Civil society does, however, have a role to play in reducing election-related conflict dynamics and promoting a peaceful electoral environment. This paper examines the role of the KwaZulu-Natal Democracy and Elections Forum (KZNDEF) in elections in KwaZulu-Natal, ${ }^{2}$ a province plagued with election-related violence since the advent of democracy in 1994. The paper is guided by the proposition that civil society organisations have a significant role to play in strengthening the quality of democracy in general.

1 Acknowledgements to Dr Rama Naidu of the Democracy Development Programme and Dr Douglas Dziva of the KwaZulu-Natal Christian Council.

2 This article is based on interviews with representatives of the five subcommittees of the KZNDEF as well as on reports prepared for the 2009 elections by the subcommittees. It also draws on reports by the various subcommittees submitted for national/provincial as well as local government elections prior to 2009 and after 1994. 
The paper is divided into three parts. The first considers the role of civil society in elections as a democratic process and also in terms of mitigating conflict and promoting peace. The second contextualises the KZNDEF within political violence and electoral processes in KwaZulu-Natal. The third part examines the impact of the KZNDEF in strengthening some of the institutional and substantive aspects of democratic elections, reducing conflict dynamics and promoting peace.

\section{CIVIL SOCIETY, ELECTION-RELATED CONFLICT AND PEACE/CONFLICT RESOLUTION ORGANISATIONS}

'Civil society', defined as 'the realm of organised social life that is open, voluntary, self generating, at least partially self supporting, autonomous from the state and bound by a legal order or set of shared rules' (Diamond 1999, p 221), is distinguished from 'society' in general on the basis that it is composed of citizens who act collectively in the public sphere to express their interests, to influence policy and to scrutinise and check the exercise of state power. Given this role, civil society is considered one of the paramount indicators of democratic consolidation (Linz \& Stepan 1996) and is linked with developmental objectives given its ability to pool individual resources in order to improve infrastructure, institutions and the quality of life of communities (Diamond 1999).

In the context of elections and, specifically, election-based conflict, civil society has been recognised as having a significant role to play in promoting peace as it is less constrained by mandates, able to talk to several parties without losing credibility, and able to deal directly with the grassroots population (Orjuela 2003). Likewise, civil society has a recognised role to play with regard to election conflict dynamics. In an article entitled 'The predicament of elections in war-torn societies' Kristine Hoglund, Anna Jarstad and Mimi Soderberg Kovacs (2009) develop a conceptual framework to identify various conflict-generating factors in the context of elections. They categorise these factors in three clusters: actors in the electoral process, institutions of elections, and election stakes.

The institutions of elections cluster is understood as being institutions relevant to the regulation and management of violence during electoral processes, including electoral management bodies, the police and the military. Hoglund et al show the impact of this cluster on conflict dynamics because of the fact that it affects perceptions of elections as legitimate and because it can provide or limit the space and opportunities for conflict behaviour (Hoglund, Jarstad \& Kovacs 2009).

Within this cluster also appear what Benjamin Gidron, Stanley Nider Katz and Yeheskel Hasenfeld (2002, p 15) term ' peace / conflict resolution organisations (P/ CROs)', which they define as 'citizens' voluntary/non-governmental organisations advocating peace/reconciliation/ coexistence between the major contenders to the 
conflict ... on the basis of mutual recognition and/or use of dispute resolution strategies as a means of addressing conflict.'

$\mathrm{P} / \mathrm{CRO}$ are formally organised voluntary citizen organisations within civil society. They promote peace, reconciliation and coexistence as well as social justice and the development of democratic institutions. The methods they employ include mutual recognition of the rights of parties to the conflict and the utilisation of dispute resolution strategies such as negotiation and dialogue. According to Gidron, Katz \& Hasenfeld (2002, p 16) P / CROs, operating within civil society, are able to represent citizens' interests by challenging the state's power by various means, such as providing alternative services that may compete with, supplant or supplement the services of the state and challenging state policies through advocacy and constituency mobilisation. Like non-governmental organisations (NGOs) in general, they are able to create social and cultural capital through the power of association and network building. 'Social capital' includes networks enabling political mobilisation and 'cultural capital', the institutionalisation of values and norms. An example of a South African P/CRO is the Institute for a Democratic Alternative for South Africa (Idasa), ${ }^{3}$ a non-profit organisation which, in 1987, before the transition to democracy, brought together Afrikaner politicians and key African National Congress (ANC) officials for discussions (Gidron, Katz \& Hasenfeld 2002). Another example, after the transition to democracy, is the African Centre for the Constructive Resolution of Disputes (Accord) ${ }_{,}^{4}$ which was set up in 1994 to help deal with Inkatha Freedom Party (IFP) and ANC conflict in the province of KwaZulu-Natal. The KZNDEF, as will be discussed further below, also meets the definition of a $\mathrm{P} / \mathrm{CRO}$.

Such organisations could be classified as part of Adam Habib's 'first bloc' within South African civil society, comprising NGOs which enjoy a collaborative relationship with the state, often being formally contracted to assist in policy development and service delivery. This bloc contrasts with Habib's second and third blocs: community based organisations of a survivalist nature that enable poor and marginalised communities to survive the daily challenges of poverty and social movements of a more political nature established to mobilise the poor in order to challenge the state about social policy (Habib 2005).

\section{POLITICAL AND ELECTION-RELATED VIOLENCE IN KWAZULU-NATAL}

While the nature of elections has, itself, the potential to instigate violence, Hoglund adds that the contextual nature of politics may be a factor contributing to election-

3 Now known as the 'Institute for Democracy in Africa', see www.idasa.org.za

4 See www.accord.org.za 
based conflict. This relates specifically to existing patron-client relationships, prevailing levels of insecurity and the potential of parties to the conflict to be armed (Hoglund 2009). KwaZulu-Natal has, to varying degrees, featured all three of these conditions. The IFP, the ruling ANC's main rival in the province, has its roots in the Inkatha movement, which governed the KwaZulu homeland during the apartheid era.

One of the principal features of the Inkatha homeland government was that it controlled its constituencies by a mixture of intimidation and incentives (Mzala 1988). These patron-client relationships were seen to survive beyond the advent of the democratic transition in 1994 and are also linked with the levels of fear and intimidation experienced by voters in KwaZulu-Natal during the initial democratic elections.

A study conducted in 1994 records testimony from rural voters revealing that there were fears of reprisal by the IFP should the ANC win the provincial election - for this reason voters felt pressured to vote for the IFP (Schlemmer \& Hirschfield 1994). The political violence in the province in the 1990s was further characterised by the fact that the conflicting parties were heavily armed. A 2002 study found that AK-47 rifles were supplied to ANC members and G3 rifles to IFP-supporting chiefs (Taylor 2002).

It is estimated that political violence in KwaZulu-Natal has claimed the lives of some 20000 since 1984, with many of these fatalities occurring after the transition to democracy (Taylor 2002).

Political violence preceding the first democratic elections has been attributed to territorial battles between Inkatha and the United Democratic Front (UDF), fuelled by the apartheid state's security forces. Political violence in the postdemocratic era has, however, been linked to lingering tensions between the IFP and the ANC (Taylor 2002). Following the advent of democratic elections these tensions have played out in the process of electoral competition for control of the province. In the 1994 election the IFP secured 50.32 per cent of the provincial vote, to the ANC's 32.33 per cent (Mottiar 2004). In the 1999 election provincial support for the IFP waned to 41.90 per cent while the ANC's grew to 39.38 per cent (Mottiar 2004). In the 2004 election ANC electoral support in KwaZuluNatal (46.98\%) overtook that of the IFP (36.82\%) (Mottiar 2004), a gain that was consolidated in the 2009 election, with the ANC securing 62.95 per cent of the vote to the IFP's 22.40 per cent (Mottiar 2009d).

In the period leading up to the first democratic election of 1994 about 1000 deaths were recorded in KwaZulu-Natal (Taylor 2002). The province was also described as demonstrating the 'most serious instance of political obstruction of free electioneering (where) within the boundaries of the KwaZulu homeland canvassing and voter education were impossible' (Lodge 1999, p 7). This was 
evidenced by incidents in which ANC canvassers were gunned down by IFP supporters in traditional IFP strongholds such as Ulundi. The 1999 provincial election, however, was described as being 'freer and fairer than ever before' (Piper 1999), with ANC canvassers gaining access to various IFP strongholds and the results more readily accepted by all parties.

The Independent Electoral Commission (IEC) also recorded fewer complaints about 'no go' zones, political violence and intimidation - in 1994 it received 3594 complaints from around the country and in 1999 the figure was reduced to 1032 (Lodge 1999). Records reveal that in KwaZulu-Natal leading up to the 1999 election there were fewer than one-tenth of the politically motivated killings than there had been during a comparable period for the 1994 election (Lodge 1999).

The 2004 provincial election was characterised by even lower levels of political violence. However, despite the end of 'open election related warfare', there was still a continuation of violence and intimidation through attacks and assassinations in various rural areas of the province, with the purpose of creating a climate of fear and compliance (Piper 2004). The 2009 election was similarly free of significant levels of election-related violence even though there were once again warnings of 'low level' political intimidation and various reports of violence at rallies and between IFP and ANC supporters (Mottiar 2009a).

Elsewhere I have suggested that the decline in violence in the run-ups to the 1999 and 2004 elections coincided directly with the IFP's loss of support in the province, the implication being that election stakes have some bearing on levels of violence (Mottiar 2004). Other explanations for the decline in violence include a view that violence is rendered less fashionable as democracy matures (Ngwenya \& Ndhlela 2004) and that people in KwaZulu-Natal are 'war weary' and not as easily stirred to violence as they once were (Mottiar 2004).

Table 1

Provincial legislature Results: KwaZulu-Natal 1994, 1999, 2004, 2009

\begin{tabular}{|c|c|c|c|c|c|c|}
\hline & \multicolumn{3}{|c|}{ ANC } & \multicolumn{3}{c|}{ IFP } \\
\hline Year & Votes & Percentage & Seats & Votes & Percentage & Seats \\
\hline $\mathbf{1 9 9 4}$ & 1181118 & 32.32 & 26 & 1844070 & 50.32 & 41 \\
\hline $\mathbf{1 9 9 9}$ & 1167094 & 39.38 & 32 & 1241522 & 41.90 & 34 \\
\hline $\mathbf{2 0 0 4}$ & 1287823 & 46.98 & 38 & 1009267 & 36.82 & 30 \\
\hline $\mathbf{2 0 0 9}$ & 2192516 & 62.95 & 51 & 780027 & 22.40 & 18 \\
\hline
\end{tabular}

Compiled from: IEC Website - www.elections.org.za \& EISA Website - www.eisa.org.za 
More convincingly, it is argued that the 'ethnically couched confrontational styles of the transition years' have given way to a more 'ideologically inclusive and cooperative politics' (Piper 1999) in the province, which has its basis in an understanding reached between the IFP and ANC in the run-up to the 1999 elections that the parties would cooperate in government whatever the outcome of the election. This agreement created a more enabling environment for free campaigning, reduced the advent of 'no go' areas and altered the nature of campaigns (Piper 1999). This may be linked to the reduction in election-related violence which continued in the run-ups to the 2004 and 2009 elections. Despite this, however, KwaZulu-Natal remains a province where the threat of election-related violence lingers and where political intimidation, 'no go' areas and campaign challenges endure, albeit at lower levels. It is in this context that the KZNDEF is constituted.

\section{THE KWAZULU-NATAL DEMOCRACY AND ELECTIONS FORUM}

The KZNDEF, a network of 17 civil society organisations most of which are part of the KwaZulu-Natal Community Based Organisation Coalition (COMBOCO), which represents some 300 organisations throughout the province, was formed in 1998 with the objective of ensuring a provincial electoral environment that would accommodate free and peaceful participation. The reason for its formation was the election-related violence, intimidation and political intolerance in KwaZuluNatal. The forum has five subcommittees: democracy and voter education, violence monitoring, mediation and conflict resolution, election observation, and legal compliance and litigation.

The democracy and voter education subcommittee, managed by the Democracy Development Programme (DDP) is responsible for training in democracy and voter education in the run-up to elections. This training is carried out through community workshops, street theatre performances and radio broadcasts. The violence monitoring subcommittee, coordinated by the KwaZulu Regional Council of Churches (KRCC), manages violence monitoring through the recruiting, training and deployment of violence monitors throughout the province before, during and after elections. The mediation and conflict resolution subcommittee, led by the KwaZulu-Natal Christian Council (KZNCC), carries out various mediation and conflict resolution activities through workshops and the training of personnel to respond to situations that arise during elections. The election observation subcommittee, managed by $\mathrm{COMBOCO}$, recruits, trains and deploys observers on election day and the legal compliance and litigation subcommittee, run by the Community Law and Rural Development Centre (CLRDC), monitors and observes law transgressors and conducts workshops on the Electoral Code of Conduct. 


\section{The democracy and voter education subcommittee - deepening democracy}

The democracy and voter education subcommittee, through its voter and democracy education workshops, facilitates the deepening of a culture of democracy and democratic citizenship in KwaZulu-Natal. It also supports the Electoral Commission (IEC) in its drive to expand civic education, with specific respect to elections. The subcommittee further plays something of a 'watchdog' role over the IEC with regard to its commitments to voters (Naidu interview).

In November 2008 the IEC reported that KwaZulu-Natal had the lowest percentage of voter registration among the provinces. It identified 2.2-million unregistered voters (Mottiar 2009a). Between August 2008 and April 2009 the subcommittee conducted more than 300 workshops in the province, reaching an estimated 9000 people in both rural and urban areas. Those reached included churchgoers, trained at local churches, and rural women and youth, trained at local community centres and school halls. The workshops were carried out by trained facilitators and focused on the procedural aspects as well as some of the more substantive elements of democracy in South Africa including the responsibility to register and vote (KZNDEF 2009a). The workshops were in line with the IEC's Civic and Voter Education Programme (IEC 2009), which aims to maximise citizen participation in electoral processes and democracy in general.

The subject matter of the workshops included definitions of democracy, systems of democracy including concepts such as the separation of powers, the three spheres of government, the Chapter Nine institutions, the Constitution, the rule of law and the Bill of Rights. There was also a focus on the electoral process, which covered the proportional representation system, voter registration, the voting process and voter rights and responsibilities, the Electoral Code of Conduct and the obligations of competing political parties.

The workshops also dealt with the concepts of human rights and equality and with the right and obligation of democratic citizens to participate in elections through both political parties and civil society organisations. Government accountability and transparency was also stressed, shifting the burden of electionrelated processes in a province where, for many years, voters had felt intimidated by authorities.

With specific regard to elections the workshops covered issues of free and fair elections, detailing how intimidation, threats and corruption impede a fair process. Workshops also stressed the idea of multiparty elections and the need for tolerance of differing opinions and acceptance of the outcome of the elections (Democracy Development Programme training manual). In a sense, the education about elections and electoral processes, stressing, as it did the undesirability of political intimidation and intolerance, the right to hold government and political 
parties accountable and the need to exercise tolerance in the context of democratic multipartyism, was geared for the KwaZulu-Natal electorate.

It was also noted that the subcommittee workshops carried out in the runups to prior elections in the province had dealt mainly with voting as a civic right and the way the voting process works. Those held before the 2009 elections, however, placed greater emphasis on making informed choices and on ways to engage constructively with local level politicians during the campaigning and electioneering phases of the election (Naidu interview). This is a clear indication that voters in KwaZulu-Natal are familiar with elections as a democratic process and are now beginning to engage with democratic citizenship through elections in a substantive way.

The specific methods employed by the subcommittee bear mention as they have an impact on the reach and range of the provincial electorate. Apart from the formal workshops in targeted rural and urban areas, democracy and voter education was also carried out through a radio drama initiative broadcast on seven community radio stations in the province and reaching an estimated 800000 listeners. The radio dramas used the voices of local artists and various characterisations to disseminate the democracy and voter education message. The serialised drama slots were followed by a listener call-in session during which in-studio representatives of the DDP and of the provincial IEC were available to answer election-related questions from the general public.

Another method employed by the subcommittee in its democracy and voter education programme was street theatre, involving a local drama group which performed work related to election issues in public spaces in the Durban area such as taxi ranks, churches and public squares. Ten such performances took place and all recorded a sound interaction with members of the public as well as a discussion session immediately following the performance. This method also allowed for the distribution of flyers and pamphlets detailing election-related issues in both English and IsiZulu (KZNDEF 2009a).

The subcommittee's democracy and voter education programme is therefore fairly well established and has been developed in such a way as to increase its reach and accessibility. It has also clearly been of an evolutionary nature, responding to the needs of the provincial electorate who, familiar with the basic voting process, are now showing signs of deeper engagement with the concept of elections and democratic citizenship.

The programme, therefore, supports the IEC's drive for an active electorate but, despite the collaborative approach, the subcommittee also plays something of a 'watchdog' role in relation to the IEC. A good example of this is the way in which a representative from every IEC voter education office is invited to attend the subcommittee's workshops and to answer any concerns expressed by those 
attending. In this way a forum is created to air the challenges of provincial voters and communicate them directly to the electoral management body.

\section{The violence monitoring subcommittee and the election observation subcommittee - reducing conflict dynamics}

The violence monitoring and election observation subcommittees have some bearing on conflict dynamics in the province at election time as they can be seen as a way of making an impact on perceptions of elections as legitimate as well as limiting the space and opportunities for conflict behaviour.

The violence monitoring subcommittee's main focus is to monitor traditional 'hot spots' and communicate relevant information to the IEC and to the police. The subcommittee plays an important role, therefore, as an early warning mechanism, highlighting areas and incidents of violence and attempting to enable the correct institutions to mitigate such violence before it escalates.

The visibility of violence monitors also went some way to curtailing incidents of violence. This was especially relevant in the run-up to the 2009 provincial election, when there were reports of ANC youth league members provoking IFP supporters, who warned that they would retaliate (Daily News 12 February 2009), while ANC party leaders accused IFP leaders of denying them the right to campaign in areas around Ulundi, Nongoma, Macambini and Estcourt (Oliphant 2009). There were also reports that the IFP had defied rally limitation bans, holding meetings in close proximity to ANC meetings and vice versa (Mercury 5 February 2009). The province deployed some 23000 police officers on election day, with special security provision for political events and rallies, claiming that 'stabilising operations and physical deployments in problematic areas' were in place (Wicks 2009).

The subcommittee recruited, trained and deployed 20 monitors to violent 'hot spots' in the province. These monitors were active before, during and after the elections. In the period before the elections the monitors detailed potential flashpoints among provincial voters. These included incidents of tampering with campaign posters and of threats and intimidation. Monitors also liaised closely with political parties in relation to rallies and campaigning. Apart from providing a good sense of electoral-related activity, this enabled political parties to monitor the implementation and observation of the Electoral Code of Conduct.

Monitors also targeted areas and institutions such as provincial universities, to observe the nature of political activity. Their choice of targets stemmed from the specialised knowledge they gained by being deployed at ground level in advance of elections. During elections, monitors focused on the voting and counting processes, interviewing voters, IEC staff and political parties to glean 
a sense of the way all parties felt about the freeness and fairness of the process. Monitors also attended where there were disputes, for example, when an electoral officer was accused of stuffing a ballot box with pre-marked ballot papers. In the period after the elections monitors continued working in the field to assess the level of acceptance of the results and any activities that may have been planned to undermine the results. They also monitored various victory celebrations in case of possible eruptions of violence (KZNDEF 2009a).

The value of local civil society organisation deploying violence monitors is that the monitors are familiar with local terrain and the organisation is familiar with provincial dynamics. The subcommittee, for example, considers violence monitoring in KwaZulu-Natal in the specific context of municipal demarcation disputes such as the Matatiele protests, the role of traditional leaders and their uncertain authority, inter- and intra-party violence and incidents of murder, strikes and protests by labour unions, the abuse and intimidation of farm workers such as in the Richmond area and taxi violence (KZNDEF 2006a). It therefore has an authoritative understanding of conflict dynamics in the province as well as the way violent 'flashes' may be projected into the elections process.

The way the subcommittee uses the information gathered by its monitors is relevant in establishing its impact. It has a formal relationship with the IEC, by whom it is accredited. This relationship takes the form of regular briefing sessions to share information and also strategies for monitoring. The subcommittee also has a formal relationship with the police and networks and communicates with various police stations in the province.

Examples gleaned from the 2006 local government elections indicate a successful working relationship between the subcommittee and other election management bodies. For instance, there was an incident in Mkhambathini municipality on election day, when IFP members were intimidating voters who they believed were ANC supporters. This led to a scuffle. Monitors immediately reported the incident to the police, who arrived and resolved the conflict before any significant violence occurred. Likewise, in the Richmond municipality, monitors received reports that farmers were forcing farm labourers to vote for the Democratic Alliance (DA). The subcommittee formally communicated this allegation to the IEC (KZNDEF 2006a).

Members of the subcommittee argue that by virtue of being a local civil society organisation they enjoy significant levels of trust from and familiarity with the provincial electorate (Buthelezi interview). The subcommittee seeks to be proactive in violence and conflict monitoring by ensuring that adequate policing and security structures are in place, particularly in trouble spots and 'no go' areas. The strategic deployment of monitors at political campaigns, rallies and marches also serves as a visible presence, acting as a deterrent to possible violent activities. 
The election observation subcommittee aims to observe the process of voting and counting on election day on behalf of civil society in KwaZulu-Natal. There were also 355 international observers and 5000 national observers during the 2009 provincial elections (Van Jaarsveld 2009a), representing the Election Monitoring Network, the African Alliance for Peace, the Southern African Development Community, the African Union Observer Mission and the Electoral Institute of Southern Africa Observer Mission.

The neutrality of a civil society observer mission such as the KZNDEF subcommittee, however, as well as the legitimacy of one entrenched in civil society in the province goes some way to rendering its findings and recommendations authoritative as well as legitimising the elections in the province in general. Van Jaarsveld (2009d), for example, argues that from a recipient perspective international observers are sometimes seen to be 'meddling' in domestic affairs and attempting to impose Westerncentric solutions. Furthermore, the short-term 'project orientated' nature of outside observer missions is also problematic, posing as it does risks of a lack of understanding and engagement with locals.

The subcommittee's observer mission during the 2009 elections comprised 550 observers recruited from civil society organisations across the province, trained in election observation and deployed to the 4191 voting stations there. Known violence 'hot spots' were prioritised. The mission observed the voting process, voting behaviour, party campaigning on election day, levels of police and security presence and the counting process (KZNDEF 2009a).

The observer mission remained in contact with an 'operation centre' set up by the subcommittee throughout election day and the 'operation centre' communicated all relevant observer mission reports to IEC offices or to the police. Incidents of violence, intimidation and dispute were also communicated to other relevant KZNDEF subcommittees. An election observation subcommittee representative maintains that, apart from its use in channelling information, the observer mission is perceived by voters in the province to be legitimate as its members are drawn from local civil society organisations whose development based work is well known.

The observer mission is also perceived as neutral as it is removed from local political and policing structures. For this reason voters on election day may well feel a sense of security in that the election is being 'watched' by a local, neutral, legitimate body, which deters the inclination as well as limiting the space to disturb the voting process (Msomi interview).

Both the violence monitoring and the election observation subcommittees have an impact on conflict dynamics in the province since they contribute to the perception of elections as being legitimate by virtue of being part of an accepted civil society sector. They also limit the space and opportunity for conflict behaviour 
both because they are visible and because they are able to pinpoint incidents of potential conflict and communicate with the relevant bodies to mitigate such incidents before they translate into full-blown conflict.

\section{The mediation and conflict resolution subcommittee and the legal compliance and litigation subcommittee - promoting peace}

The mediation and conflict resolution subcommittee and the legal compliance and litigation subcommittee play a fairly significant role in the promotion of peace during election periods in the province as they are able to convene various neutral stakeholders while also being able to target legitimately and represent the grassroots population, drawing them more fully into the process.

The mediation and conflict resolution subcommittee is structured to enable stakeholders at all levels to be represented and convened. It also provides a neutral and legitimate avenue for mediating and resolving potential conflict as well as providing a platform for peace building.

The subcommittee, comprised of 80 mediators, is structured on two levels. The first, designed to operate at a local level, is made up of mediators recruited from civil society organisations in the province and represents women, the youth and community members. The second, designed to operate at a more elite level, is made up of eminent members of church, social and business communities in the province. The first level targets conflicts such as altercations during campaigning or the destruction of campaign material by competing parties. The second level convenes and mediates among political parties and representatives of traditional leaders with regard to issues such as intimidation, permission to hold rallies and 'no go' areas (Dziva interview).

Mediators are generally expected to intervene and mediate in cases where the Electoral Code of Conduct is violated. Mediators at both levels are recruited with regard to their previous experience in mediation and conflict resolution and their familiarity with electoral processes. They are also required to be neutral and therefore may not hold rank in a political party or be perceived as aligned with any particular political party or independent candidate.

The most serious incident of an election-related dispute in KwaZulu-Natal during the 2009 election occurred in Wembezi Township outside Estcourt, where ANC and IFP supporters clashed (Mbanjwa 2009). Among some of the issues dealt with by the mediators in the 2009 and in previous provincial as well as local elections were: disputes between election candidates, reports of intimidation and obstructing parties' rights to campaign freely, disputes over vandalised campaign materials, disputes related to campaigning, disputes related to voter registration and disputes relating to the recruitment of electoral personnel by the IEC. 
The subcommittee's neutrality is obviously of great value in such circumstances as the disputes span various election stakeholders from political parties to the electoral management body and ordinary voters. Examples from the 2006 local government elections illustrate how mediation at high as well as low levels has proven effective. The first example is that of election campaign poster defacing. Local level mediators discovered that the perpetrator was a local tenyear-old. Through links with the community and the family this situation was successfully resolved.

The other example involved post-election conflict/intimidation aimed at some newly elected political councillors in Shobashobane, Estcourt and KwaMaguda. High-level mediators remained involved in these cases well after the elections, which indicates the sustainability of the peace-building process with regard to the acceptance of the election results and a tolerance for competing political party agendas (KZNDEF 2006b).

The legal compliance and litigation subcommittee provides an accessible way to bring political parties, electoral management bodies and provincial voters together in order to outline the process of elections, the challenges faced by all stakeholders and mechanisms of overcoming them or seeking recourse. The subcommittee therefore provides a forum for all election stakeholders to consider peaceful ways to overcome election-related challenges or frustrations. Bringing stakeholders together in a common space towards a common goal legitimises peace as opposed to conflict and binds those present to further this goal.

In the run-up to the 2009 elections the subcommittee held a number of workshops across the province, two of which were significantly intensive and were attended by up to 80 people. Among those who attended the workshops were voters from communities around the province, representatives of the IEC and the police, various political as well as traditional leaders and political parties. The purpose of the workshops was to provide information about the legislation governing elections in South Africa, including prohibited conduct and penalties for breaches of the Electoral Code of Conduct, and to educate those attending about the process for lodging complaints. The workshops also dealt with electoral responsibility, promoting political tolerance, and the acceptance of results (Mtshali interview).

The South African Electoral Act (1998) provides that parties have the right to lodge electoral complaints that are material to the final outcome of the election. In KwaZulu-Natal the IEC received 71 complaints during the 2009 elections, relating to the damaging of posters, the interruption of meetings and other acts of political intolerance (Van Jaarsveld 2009c). During those elections the subcommittee dealt with formal complaints about the defacing of posters and the inability of some parties to secure venues for political meetings. 
In both instances the subcommittee liaised with the police and relevant municipality to ensure that equality in campaigning was promoted. Through its work the subcommittee has highlighted two issues that have had an impact on conflict dynamics in the province in the last sets of elections. The first is that of campaigning on election day by wearing political party clothing. While official party campaigning is prohibited on election day this does not extend to clothing worn by voters, or campaigners. Definitions of campaigning, therefore, need to be clarified in order that a free and fair electoral process is not hampered.

The second issue is that of authorisation of the use of public spaces for party campaigning/meetings. Venues under the mandate of various local councils or traditional leadership structures have been seen to be used and booked strategically (KZNDEF 2009a) which effectively limits open and free spaces for campaigning and association.

The highlighting of these issues, if channelled effectively and dealt with by the appropriate structures, would go some way to reducing two potential sources of conflict in the province and underscores the usefulness of a civil society oversight role.

The mediation and conflict resolution subcommittee and the legal compliance and litigation subcommittee both contribute to the promotion of peace during election periods in KwaZulu-Natal. The fact that they consist of members of local civil society organisations who are well known to voters in the province gives them high levels of trust and legitimacy among stakeholders across the board valuable qualities in a peace promoting or peace building process. Their neutral status also allows them to bring stakeholders together with a common purpose, reducing the terrain of differences that may cause conflict.

\section{THE KZNDEF - A PEACE / CONFLICT-RESOLUTION ORGANISATION}

The KZNDEF meets the criteria of a P/CRO in that it is a voluntary organisation that promotes peace through a recognition of the rights of all parties and through the use of conflict resolution strategies such as negotiation and dialogue. It also promotes the development of democratic institutions such as the electoral process through its democracy and voter education initiatives. In this sense it could be seen as a civil society organisation working at the local level to further the aim of peace via conflict resolution activities that will ultimately have an impact on facilitating grassroots community development through a respect for local values and expertise (O'Brien 2005). In terms of building 'cultural capital' the violence monitoring and election observation projects may go some way towards institutionalising positive norms of democratic behaviour and tolerance during elections. In terms of building 'social capital' to enable political mobilisation to 
'challenge and change the forces that fuel and maintain conflicts and prevent peace' (Gidron, Katz \& Hasenfeld 2002, p 17), however, the KZNDEF is less successful, probably because it is operating within a democratic arena in which institutions and processes of democracy are already in operation, but also because it probably sees itself as playing a more collaborative/supporting rather than adversarial role vis à vis the state.

\section{CONCLUSION}

While it is not possible to attribute lower levels of election-related conflict and higher levels of peace during elections in KwaZulu-Natal directly to the work of the KZNDEF it is possible to suggest that the forum has made significant progress in promoting a democratic spirited electorate more inclined towards peaceful rather than conflict-based elections.

Although there has been a reduction in election-related physical violence, 'no go' areas, significant intimidation and election-related complaints in the province there are still potential 'flashpoints'. The KZNDEF has built extensive capacity to respond to conflict and promote peace, including the establishment of a pool of election observers, monitors, mediators and skilled trainers. The forum also has a significant working relationship with electoral management and law enforcement bodies in the province, which enables it to balance its entrenched legitimacy as a civil society organisation representing the grass roots.

The specific functions of each of the KZNDEF's subcommittees also go some way towards alleviating some of the contextual political factors referred to above. The education initiatives and formal mediation and conflict resolution measures attempt to reverse the patron-client culture, while the violence monitoring and election observation aspects have an impact upon levels of fear and intimidation and the legal compliance and litigation work may reduce impunity and, certainly, perceptions of impunity.

The KZNDEF is, however, restricted by challenges of financing and capacity (KZNDEF 2009a) which affect the reach, function and level of follow through of its subcommittees. More research is required to understand the actual impact of the forum on the grassroots voters it sets out to represent. Its working relationship with the IEC and police service also requires further consideration. In the context of its role in elections as a civil society organisation it would be useful to investigate how neutral the KZNDEF really is, given its strategic relationships with both the IEC and police structures.

It would also be worthwhile examining its actual membership more closely in terms of how representative it is of the provincial grassroots. Furthermore, its ability to make an impact on institutional and policy development within the 
ambit of election-based conflict in the province would prove a valuable study. What is clear, however, is that the KZNDEF currently bears a fair burden within the province of KwaZulu-Natal with respect to ensuring a responsible electorate and a free and fair election process.

\section{- REFERENCES}

Buthelezi, R. 2010. KRCC, interview, 8 June, Durban.

Daily News 12 February 2009.

Democracy Development Programme. nd. Democracy and you: A community manual on governance and participation in the new South Africa. Durban: DDP.

Diamond, L. 1999. Developing democracy: Toward consolidation. Baltimore: The Johns Hopkins University Press.

Dziva, D. 2010. KZNCC, interview, 9 June, Pietermaritzburg.

Electoral Act of South Africa 73, 1998.

Gidron, B, SN Katz, \& Y Hasenfeld (eds). 2002. Mobilizing for peace: Conflict resolution in Northern Ireland, Israel / Palestine and South Africa. Oxford: Oxford University Press.

Habib, A. 2005. 'State-civil society relations in post apartheid South Africa'. Social Research 72(3).

Hoglund, K. 2009. 'Electoral violence in conflict ridden societies: Concepts, causes and consequences'. Terrorism and Political Violence 21.

— - A Jarstad, M S Kovacs. 2009. 'The predicament of elections in war-torn societies'. Democratisation 16(3).

Independent Electoral Commission. 2009. Elections Report. Pretoria: Electoral Commission of South Africa.

KwaZulu-Natal Democracy and Elections Forum. 2000. Municipal elections 2000 report. Pietermaritzburg: KZNCC.

-2006a. Violence monitoring project report. Pietermaritzburg: KZNCC.

-2006b. Mediation and conflict management project. Pietermaritzburg: KZNCC.

- 2009a. Report on the national elections in South Africa 2009. Durban: DDP.

- Progress report for monitoring in KwaZulu-Natal. Durban: KRCC.

- Preliminary report on South Africa elections observation mission in KwaZulu-Natal province 18-23 April 2009. Pietermaritzburg: KZNCC.

- 2009 d. Election Monitoring Network final report for election monitoring in KwaZulu-Natal. Pietermaritzburg: KZNCC.

Linz, J, J \& AStepan. 1996. ‘Toward consolidated democracies'. Journal of Democracy $7(2)$. 
Lodge, T. 1999. Consolidating Democracy: South Africa's Second Popular Election. Johannesburg: Witwatersrand University Press.

Mbanjwa, B. 2009. 'Estcourt a hotspot'. Daily News 23 April.

Mottiar, S. 2004. 'The turnover of power in KwaZulu-Natal: A growing commitment to and engagement with the democratic process'. Journal of African Elections $3(2)$.

—.2009a. EISA Election Update South Africa, 2009, 1: KwaZulu-Natal. Johannesburg EISA.

----. 2009b. EISA Election Update South Africa, 2009, 3: KwaZulu-Natal. Johannesburg: EISA

----.2009c. EISA Election Update South Africa, 2009, 4: KwaZulu-Natal. Johannesburg: EISA.

----.2009d. EISA Election Update South Africa, 2009, 8: KwaZulu-Natal. Johannesburg: EISA

Mercury 5 February 2009.

Msomi, V. 2010. COMBOCO, Interview, 14 June, Durban.

Mtshali, L. 2010. CLRDC, Interview, 15 June, Durban.

Mzala. 1988. Gatsha Buthelezi: Chief with a Double Agenda. London: Zed Books.

Naidu, R. 2010. DDP, Interview, 7 June, Durban.

Ngwenya, T \& N Ndhlela. 2004. 'Political parties and political identities: How relations between the ANC and IFP play themselves out in KwaZulu-Natal'. Election Synopsis 12. Johannesburg: Centre for Policy Studies.

O'Brien, C. 2005. 'Integrated community development/conflict resolution strategies as "peace building potential" in South Africa and Northern Ireland". Community Development Journal 42(1).

Oliphant, N. 2009. 'Parties pledge peace amongst verbal attacks'. Mercury 4 March.

Orjuela, C. 2003. 'Building peace in Sri Lanka: A role for civil society'. Journal of Peace Research 40(2).

Piper, L. 1999. 'Democracy for a bargain: The 1999 election in KwaZulu-Natal'. Politikon 26(2).

- 2004. 'Politics by other means: The practice and discourse of violence in KwaZulu-Natal'. EISA Election Update South Africa, 4.

Schlemmer, L \& I Hirschfield. 1994. Founding Democracy and the New South African Order. Pretoria: Human Sciences Research Council.

Taylor, R. 2002. 'Justice denied: Political violence in KwaZulu-Natal after 1994'. Violence and Transition 6.

Van Jaarsveld, S. 2009a. EISA Election Update South Africa, 2009, 5: KwaZulu-Natal. Johannesburg: EISA. 
----.2009b. EISA Election Update South Africa, 2009, 6: KwaZulu-Natal. Johannesburg: EISA.

--_-_2009c. EISA Election Update South Africa, 2009, 7: KwaZulu-Natal. Johannesburg: EISA.

--_-. 2009d. EISA Election Update South Africa, 2009, 9: KwaZulu-Natal. Johannesburg: EISA.

Wicks, J. 2009. 'Safeguarding the elections'. Mercury 15 April. Johannesburg: EISA. 